\title{
Augmented Reality as a Tool for Promoting the Tourist Value of the Geological Heritage Around Natural Filming Locations: a Case Study in "Sad Hill" (The Good, the Bad and the Ugly Movie, Burgos, Spain)
}

\author{
José Ángel González-Delgado ${ }^{1}$ • Antonio Martínez-Graña ${ }^{1}$ • Marina Holgado ${ }^{1}$ • Juan Carlos Gonzalo ${ }^{1}$. \\ Paulo Legoinha ${ }^{2}$
}

Received: 7 May 2019 / Accepted: 24 March 2020

(C) The European Association for Conservation of the Geological Heritage 2020

\begin{abstract}
Some natural scenes of films shooting contain landscapes and other elements that are part of the geological heritage, representing an added value for the growing cultural tourism that visits them. In the SE of Burgos province (Spain), near some filming locations of the classic western movie directed by Sergio Leone (1966), "The Good, the Bad and the Ugly", we have assessed the Geological Heritage of 6 selected sites: (1) Dinosaur tracks; (2) Paleo-river structures preserved; (3) Fossil trees; (4) Sad Hill; (5) Marine Cretaceous fossils; and (6) La Yecla Gorge. Their tourist-cultural, scientific and educational values range from 775 points in La Yecla Gorge site to 450 in Marine Cretaceous fossils site. A virtual tour is presented implementing Augmented Reality on Google Earth with detailed but easily understanding descriptive information of each site, suggested activities for tourism and a free geoapp. The proposed technologies can enhance geotourism, favouring sustainable development and fostering attitudes and skills related to the tourist's respect for nature.
\end{abstract}

Keywords Digital geotourism · Palaeontology and geomorphology $\cdot$ Filming location Sad Hill $\cdot$ Burgos-Spain

Electronic supplementary material The online version of this article (https://doi.org/10.1007/s12371-020-00457-4) contains supplementary material, which is available to authorized users.

Antonio Martínez-Graña

amgranna@usal.es

José Ángel González-Delgado

angel@usal.es

Marina Holgado

marina4hm@usal.es

Juan Carlos Gonzalo

jcgonzalo@usal.es

Paulo Legoinha

pal@fct.unl.pt

1 Department of Geology, Science Faculty, University of Salamanca, Plaza de los Caídos s/n, 37008 Salamanca, Spain

2 Geobiotec, Departamento de Ciências da Terra, Faculdade de Ciências e Tecnologia, Universidade Nova de Lisboa,

2829-516 Caparica, Portugal

\section{Introduction}

There is a general consensus on the fact that tourism specialised in nature (landscape, geology, biodiversity, fossils) is increasing rapidly in recent decades (Balmford et al. 2009; Sriarkarin and Lee 2018), although studies such as Pergams and Zaradic (2008) show that the number of tourists visiting public lands in the USA, Japan and Spain has declined over the last two decades.

Geotourism is a recent form of nature tourism based on the geosystem (Newsome and Dowling 2010; Dowling 2013), but due to fast growth and capacity of attracting a high number of tourists, its management challenges are many (Newsome et al. 2012). Geotourism also represents a new and important line of research at a global scale (see Ruban 2015 for a review of 165 papers of 417 specialists from 45 countries, between 2012 and 2014).

Tourism that visits natural environments can observe its biodiversity in situ, but it is also desirable to look to its geodiversity since both promote awareness and sensitivity for the environment and facilitate the understanding and respect for nature. 
Few papers have analysed the relation between the natural locations used in filming by the media and the observable geology of the area (e.g. Lugeri et al. 2015). However, when visible geology for its importance can be part of the geological heritage, undoubtedly enhances the cultural patrimony of the region and may raise the interest of cultural groups, students and tourists in general, to visit them.

The importance acquired by geomatics tools and Augmented Reality techniques, free of charge and easily implemented in mobile devices, currently makes possible the digital geotourism, allowing anyone to know the value of geological places of interest (GIPs) in a simple and interactive way. These aspects have already been implemented in rural mountain areas of the Salamanca province (West of Spain) with low tourist occupation (Martínez-Graña et al. 2014, 2017a) or in areas with a high-density touristic activity such as the Algarve (South of Portugal) (Martínez-Graña et al. 2017b). Furthermore, new technologies facilitate the creation of updated virtual geodatabases in official geoportals, and the access in real time to information about the geological heritage (Bailey and Chen 2011; Martínez-Graña et al. 2013, 2018; Cayla et al. 2014).

In the SE of the province of Burgos (Castilla y León, Spain), geotourism is increasing, in recent years, since there are important paleontological sites of the Cretaceous period (between 145 and 65 million years ago). Numerous dinosaur tracks (Bengoechea et al. 1993; Moratalla et al. 1994) and fossil trees (converted into silica) occur in the rocks formed from sediments deposited when the area was part of a terrestrial ecosystem. However, other rocks contain fossils of marine molluscs witnessing the existence of an ancient sea that invaded the previous terrestrial ecosystem with trees and dinosaurs. Also noteworthy is the landscape with a diversity of geoforms, including several gorges. In order to develop

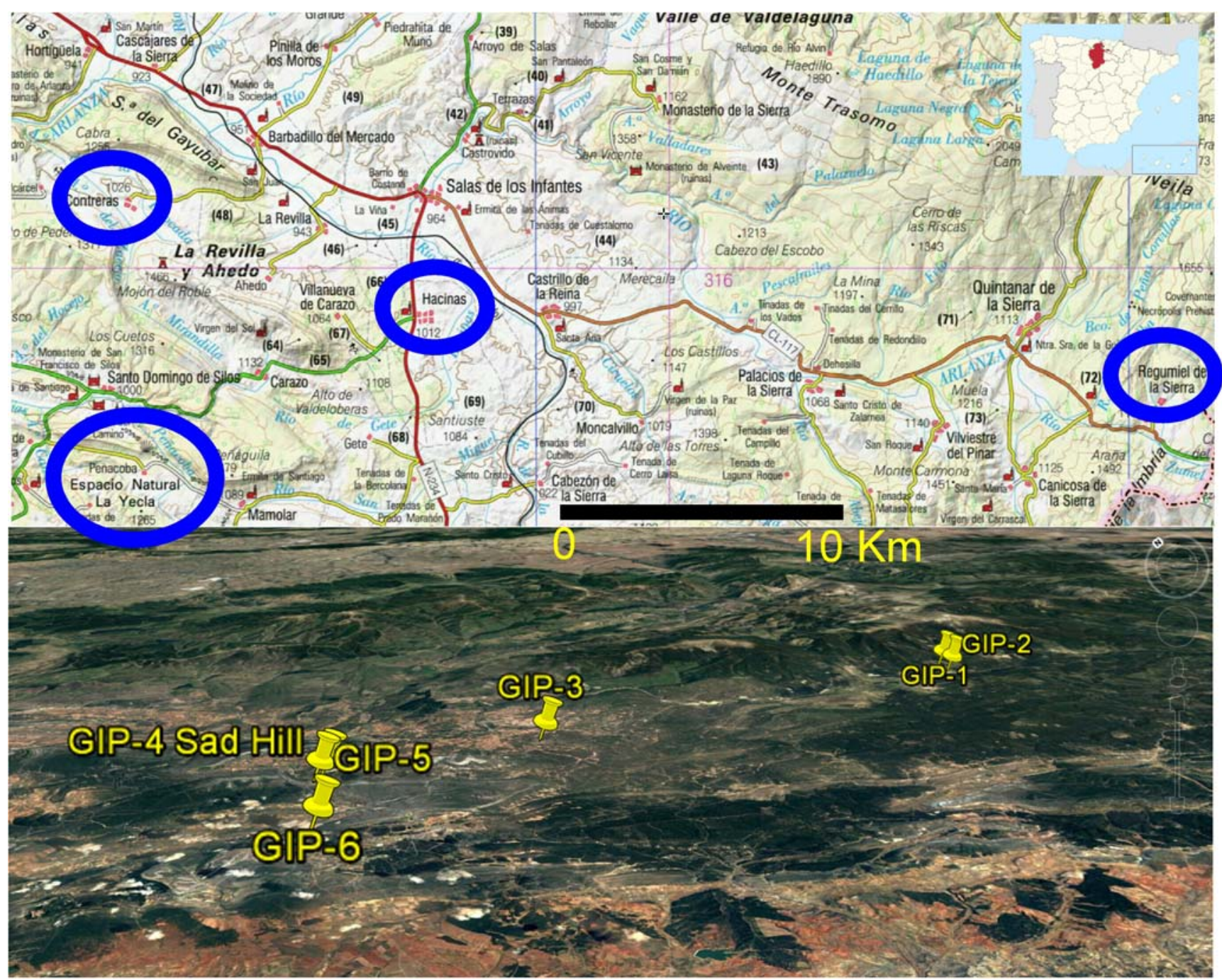

Fig. 1 Study area and location of the GIPs 
tourism in the area, some places were intervened to preserve their content, and explanatory panels and even 3D models in real scale of some Dinosaurs installed (Fig. 4a).

Among all the geological variety observable in an areathe local geodiversity - there are some sites of greater relevance, which are part of the Geological Heritage (a set of natural geological resources with high scientific, tourist, cultural and educational value). These places can be valued in a quantitative way using a simple methodology (García Cortés and Carcavilla 2018). The results obtained help managers, students and the general public to know the interest of each site.

In this area, during the summer of 1966, different scenes of the well-known Sergio Leone's western movie "The Good, the Bad and the Ugly" were filmed. The unique landscape with millenary junipers and limestone escarpments of Peña de Carazo and the Arlanza River valley convinced Sergio Leone and his team for its similarity to the natural scenery of the New Mexico and the Rio Grande in Santa Fe, and Glorieta Pass (USA). Some famous scenes filmed in different municipalities were the concentration camp of Betterville, in Carazo; the battle of Langstone bridge, in Hortigüela and Contreras; and the best known, the final duel lasting $20 \mathrm{~min}$ in the cemetery of Sad Hill, in Contreras (Fig. 1). Over the years, these scenarios become hardly recognisable on the ground. But thanks to the effort of cultural associations of Salas de los Infantes, such as the Center of Tourist Initiatives of Sierra de la Demanda, the Sad Hill Cultural Association, and the
Archaeological and Paleontological Collective, the area around the final duel scene (the so-called Sad Hill cemetery) has been partially restored. About 2000 tombs were reconstructed of the nearly 5000 that appear in the film. Also, vegetation coverage of the central cobbled square was removed allowing perfect recognition of the local where the scene took place. The "Geology day 2016" in Burgos province (http:// www.sociedadgeologica.es/archivos_pdf/geolod\%C3\% ADa16/guias_geolodia16/gdia16gui_burgos.pdf) promoted by the Geological Society of Spain was carried out in the Sad Hill (Huerta et al. 2016). In October 2018, the Spanish movie (83') of Guillermo de Oliveira, Desenterrando Sad Hill (Sad Hill Unearthed), had his premiere, narrating this reconstruction (https://www.youtube.com/watch?reload $=9 \& \mathrm{v}=$ OUU7auBwyI0). In this work, we intend to give a further tourist incentive for people wanting to visit the natural setting of an iconic film shooting, through Augmented Reality techniques and information on the visible geological environment, partly constituting the geological heritage (paleontological sites, landscape, gorges) of the area, as an additional tool to increase tourism. The objective of this study was to identify, classify and evaluate six points of geological interest (GIPs) (Fig.1) to perform a geological itinerary. Once identified and selected, were qualitatively and quantitatively evaluated, and downloadable georesources generated a geoapp and a 3D virtual flight using the Google Earth application.

Table 1 Geosite values (left) and weighting coefficients (right)

\begin{tabular}{|c|c|c|c|c|c|c|c|c|c|}
\hline Geosites & 1 & 2 & 3 & 4 & 5 & 6 & Scientific & Educational & Tourist \\
\hline Representativeness & 2 & 1 & 4 & 2 & 1 & 2 & 30 & 5 & - \\
\hline Character type locality & 2 & 0 & 2 & 1 & 0 & 1 & 10 & 5 & - \\
\hline Degree of scientific knowledge of the location & 2 & 1 & 2 & 1 & 1 & 2 & 15 & - & - \\
\hline State of conservation & 2 & 4 & 2 & 4 & 2 & 4 & 10 & 5 & - \\
\hline Viewing conditions & 4 & 4 & 2 & 4 & 2 & 4 & 10 & 5 & 5 \\
\hline Rarity & 2 & 1 & 1 & 2 & 1 & 1 & 15 & 5 & - \\
\hline Geological diversity & 0 & 1 & 1 & 2 & 1 & 2 & 10 & 10 & - \\
\hline Learning objectives/educational use & 4 & 2 & 4 & 4 & 2 & 4 & - & 20 & - \\
\hline Logistics infrastructure & 4 & 4 & 2 & 2 & 4 & 4 & - & 15 & 5 \\
\hline Population density & 1 & 1 & 1 & 1 & 1 & 1 & - & 5 & 5 \\
\hline Accessibility & 2 & 4 & 4 & 1 & 1 & 4 & - & 10 & 10 \\
\hline Intrinsic fragility (geosite size) & 1 & 1 & 2 & 2 & 1 & 2 & - & 5 & 15 \\
\hline Association with elements natural and/or cultural & 2 & 2 & 2 & 4 & 4 & 4 & - & 5 & 5 \\
\hline Beauty or spectacularity & 2 & 0 & 1 & 2 & 1 & 2 & - & 5 & 20 \\
\hline Informative content/use & 4 & 2 & 4 & 4 & 2 & 4 & - & - & 15 \\
\hline Potential for tourism/recreation activities & 2 & 0 & 4 & 4 & 1 & 2 & - & - & 5 \\
\hline Proximity to recreational areas & 1 & 1 & 0 & 0 & 0 & 0 & - & - & 5 \\
\hline Socioeconomic environment & 1 & 1 & 1 & 1 & 1 & 1 & - & - & 10 \\
\hline Total & 38 & 30 & 39 & 41 & 26 & 44 & 100 & 100 & 100 \\
\hline
\end{tabular}



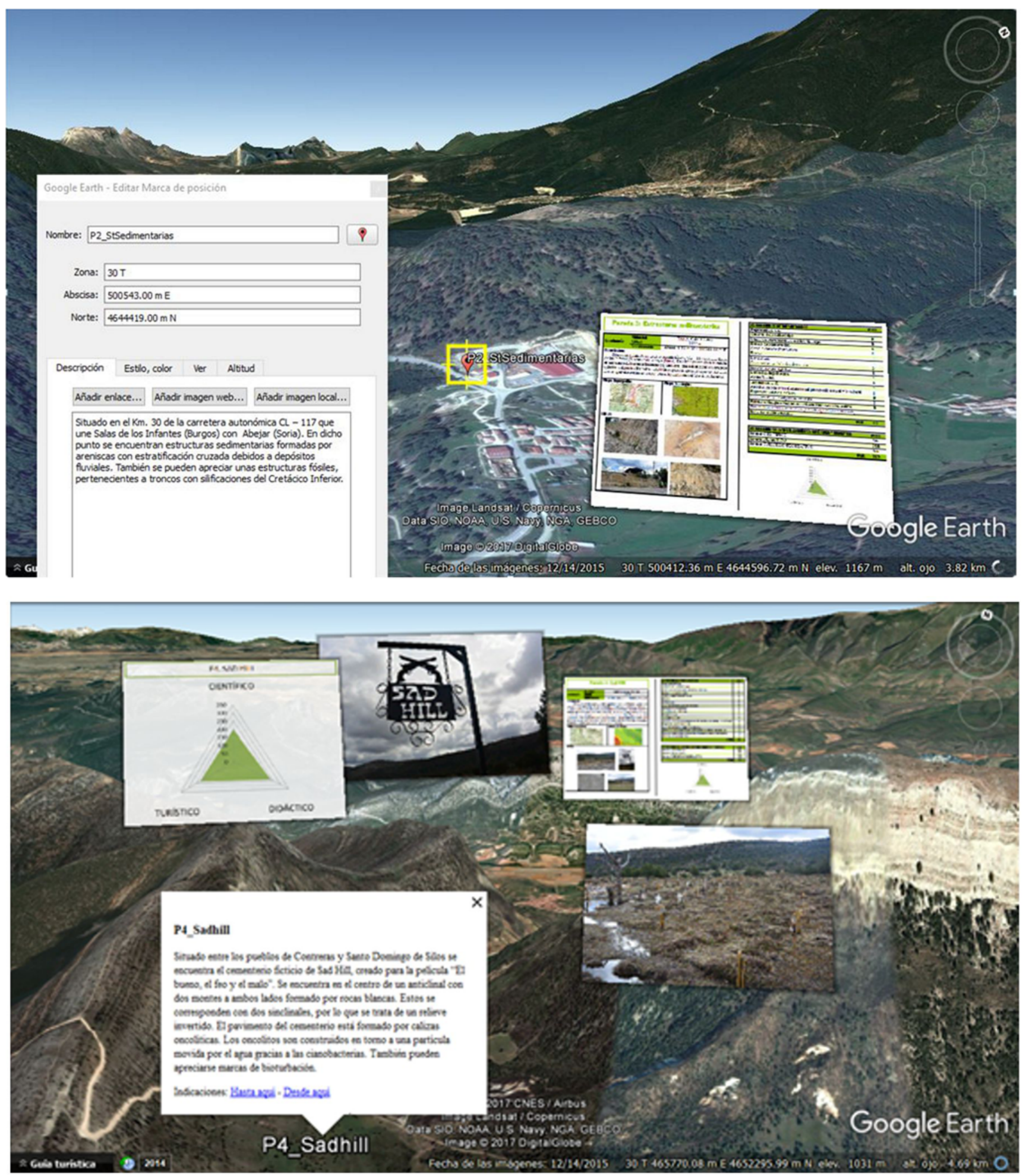

Fig. 2 Screenshots of GIP 2 showing the placemark (up), and the description, pictures in flight, information sheet and other resources (down) 

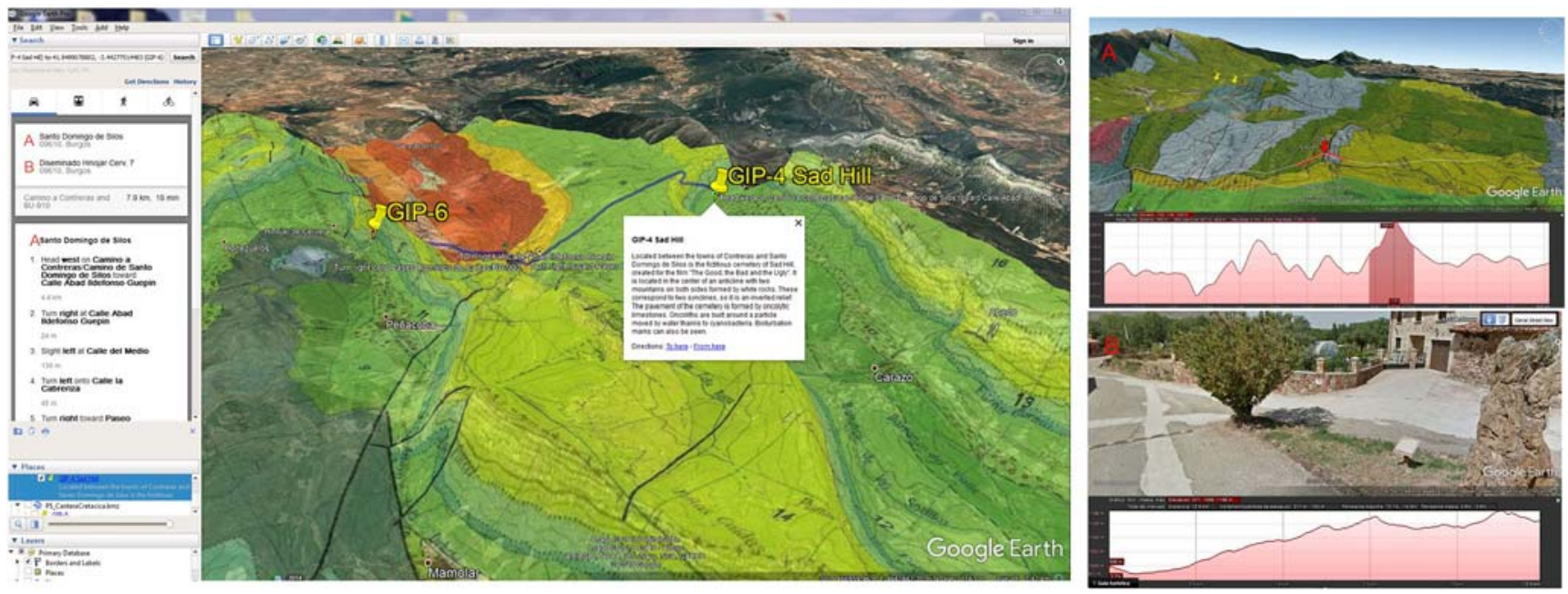

Fig. 3 From left to right: table of contents (geodatabase). Visual route from the GIP4 to the GIP 6 (blue colour), suggested by the GPS of the mobile device. a Topographic profile of the route. b Street view capture of site 3

\section{Materials and Methods}

\section{Valorising the GIPs}

The evaluation of the GIPs has been carried out according to the methodology proposed by the Spanish Geological Survey (Geological and Mining Institute, IGME) (García Cortés and Carcavilla 2018), based on the assignment of 0 to 4 points to a total of 18 parameters (Table 1, left) concerning its representativeness, size, type locality character, scientific knowledge of the place, conservation, accessibility, observation conditions, rarity, infrastructures in the area, population density, association with other eco-cultural elements, beauty, potential to carry out informative activities, proximity to recreational areas and socioeconomic environment of the place. The value obtained for each parameter is then multiplied by a weighting coefficient depending on the type of value (scientific, educational or tourist) to be calculated (Table 1, right). The final score of the GIP is obtained summing the three values.

The selected GIPs were (1) Dinosaur tracks of Regumiel de la Sierra; (2) Paleo-river sedimentary structures at the same village; (3) Fossil trees in Hacinas; (4) "Sad Hill" site in Contreras; (5) Marine Cretaceous fossils in Contreras; and (6) "La Yecla Gorge" in Santo Domingo de Silos (Fig.1).

\section{Virtual 3D Route on Google Earth Platform}

Once the sites have been identified, catalogued and qualified, were geo-referenced with UTM coordinates. The Google Earth platform has been used for placement of the GIPs in a $3 \mathrm{D}$ virtual globe and gets its geo-referenced information in a simple way in different devices. The information is accessible online, from any place or during the route between the stops of the itinerary, facilitating the location of the GIPs and increasing the interactivity.
The implementation of each GIP was done using placemarks including a brief description of the area, and the information sheet with field photographs, graphics and interpretations. Its scientific, educational and tourist-cultural value was also indicated (Fig.2).

All GIPs generate a geodatabase in " $\mathrm{kml} / \mathrm{kmz}$ " format (Fig.3) that allows to virtually visit each site in real time, and download specific resources including the quantitative assessment and the location within the itinerary. It is also possible to set the route to the next GIP (to here/from here).

By opening each file, the virtual platform automatically geo-reference the selected stop. The application allows the user to move closer or away from each GIP, providing simple information about the geological context and offering a spatial view of the itinerary with several 3D geological materials, enabling the visualisation of the topographic position and the variety and antiquity of the rocks that surround him.

The application itself creates the virtual route with all the information, using by default the roads and paths that lead from one site to another, or it may be defined by the user, manually, choosing the path to follow. In the first case, the GIP information appears in the window on the left, with indications similar to those of a GPS, as well as the different transport options (car, public transport, walking, cycling, etc). When the user decides the route, he can interact with the "StreetView" application of Google Maps, observing the outcrops "in situ". In both situations, it is also possible to obtain a topographic profile of the route, to previously know the slope of the terrain and its difficulty (Fig. 3).

The proposed route follows a geographical criterion considering the order of the stops (see supplementary materials) and usefulness for easy orientation of the tourists, so the layout is not based on the age of rocks and fossils of each site, as it should be from the most logical scientific point of view. This 

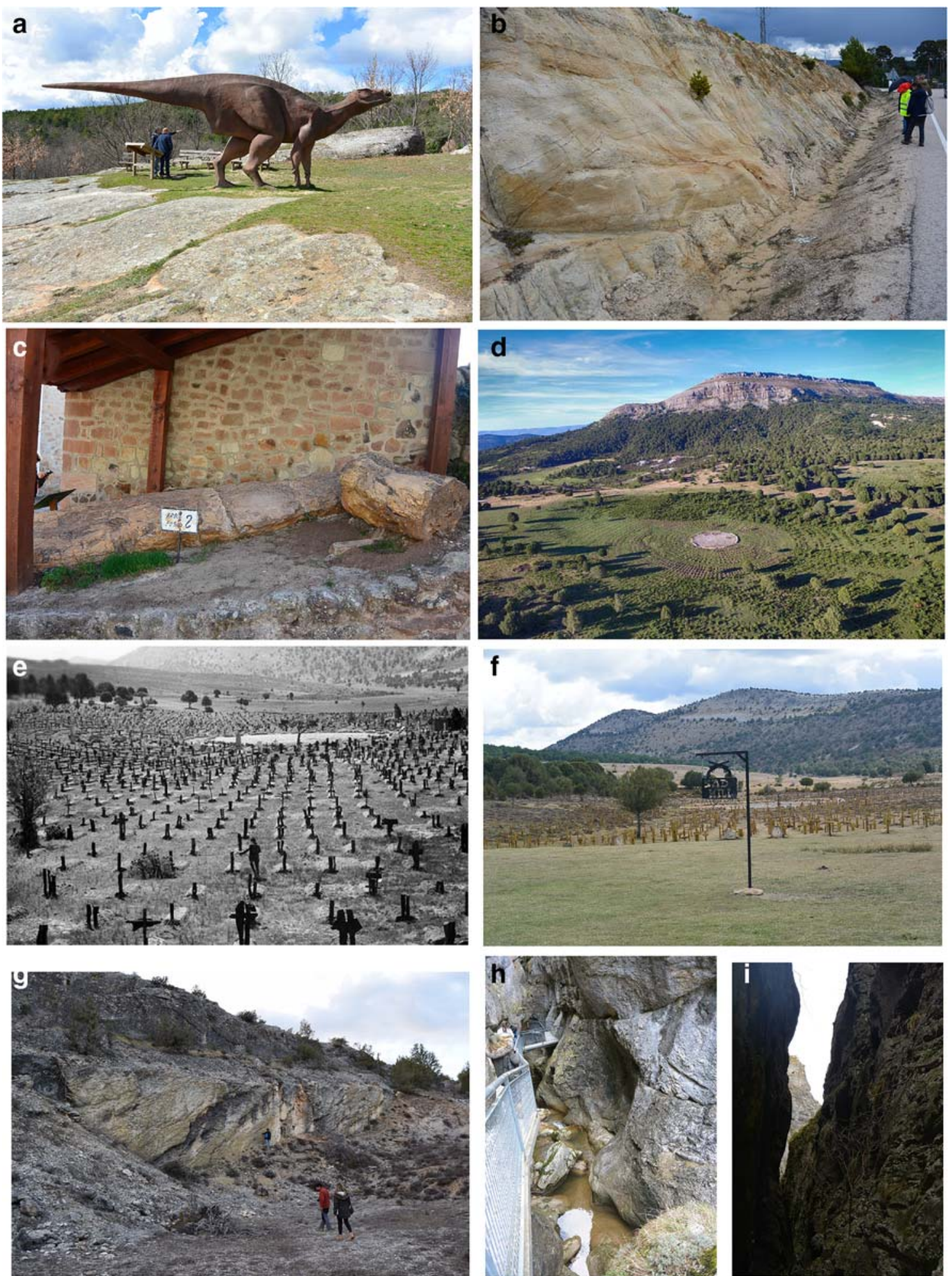

Fig. 4 a Dinosaur tracks of Regumiel (GIP 1). b Paleo-river structures in Regumiel (GIP 2). c Fossil tree of Hacinas (GIP 3). d Aerial view of Sad Hill, with its former Roman theatre shape. e Sad Hill cemetery in 1966. f

facilitates easy understanding by all types of public and optimises the duration of the route, which is generally appreciated by the tourist.
Sad Hill today (GIP 4). g Cretaceous marine fossils quarry (GIP 5). h, i La Yecla Gorge (GIP 6)

Afterwards, a 3D virtual flight was made using the "record tour" command. The flight comprises a tour over the map, according to the selected route for the different GIPs and 
respective photographs, displayable on the Smartphone or downloadable in video formats (avi, Mpeg) (see supplementary materials).

\section{Creation of a Geoapp}

Another resource is the creation of a geoapp, in several languages, which contains detailed information for the tourist (geological, paleontological, landscape ...) using the internet access and the GPS of the device.

This application has been generated using the Android creator platform (Weng et al. 2012) for mobile devices and Android tablets, enabling the easy development of free applications, with no need of programming skills. The application shows the information about the proposed route by entering the data for each site on the platform assistant. In addition, it displays the information on Google Maps allowing to send messages about the GIPs directly to social networks and to attach links. One of these links may be connected to a field guide, allowing "in situ" activities and the assessment of the degree of understanding of the informative content of the site by the participants.

\section{Results}

The six GIPs are located in two readily accessible zones, a fundamental requisite for tourism purposes. The first two stops (ichnites and fossil fluvial structures) are in Regumiel de la Sierra. The other four at the north of Santo Domingo de Silos. All GIPs can be easily reached by any vehicle, through paved or dirt roads. Some of them have a small route or are very close to each other, allowing the visitor to walk, observe and discover an area of great beauty with multiple geological, zoological, botanical and cultural interests.

\section{Description of the GIPs}

GIP 1: Dinosaur tracks of Regumiel. In Regumiel de la Sierra, there are two deposits, called El Frontal and Frontal II, presenting a large number of ichnites. Most were formed by Iguanodontid dinosaurs dominant herbivores at the beginning of the Cretaceous, whose most striking feature is his thumb

Table 2 Values for the scientific, educational and tourist interest of the six selected GIPs

\begin{tabular}{lllllll}
\hline Geosites & 1 & 2 & 3 & 4 & 5 & 6 \\
\hline Scientific interest & 210 & 150 & 235 & 205 & 120 & 215 \\
Educational interest & 250 & 225 & 245 & 250 & 185 & 305 \\
Tourist interest & 225 & 155 & 205 & 225 & 145 & 255 \\
$\quad$ Total & 685 & 530 & 685 & 680 & 450 & 775 \\
\hline
\end{tabular}

transformed into a spur. These footprints are found on what once were sands deposited in the channels and fluvial plains of large rivers $125 \mathrm{Ma}$ ago (Fig. 4a). The total weighted assessment (Table 1) is 670, of which 200, 255 and 215 correspond to its scientific, educational and tourist value.

GIP 2: Paleo-river structures. Located at $30 \mathrm{~km}$ of the regional highway CL-117 connecting Salas de los Infantes (Burgos) to Abejar (Soria). At this point (Fig. 4b), there are sedimentary structures not produced by organisms, the socalled cross stratification, consisting of arrangements of thin fluvial sedimentary strata deposited at an angle to the main stratification. The total weighted assessment is 525 , of which 135,235 and 155 correspond to the scientific, educational and tourism value, respectively.

GIP 3: Hacinas fossil trees. Remains of fossil trees, that is silicified wood from the Lower Cretaceous, 120 million years ago, in the historic town of Hacinas. It constitutes the first record of the genus Protopodocarpoxylon. Its morphology highlights the favourable climatic conditions of the area, at that time, with abundant water availability. In the urban centre, four fossil trees are exposed (Fig. 4c), and there is an Interpretation Centre for tourism. The total weighted assessment is 705 , the second highest in the route, of which 235,255 and 215 correspond to the scientific, educational and tourist value, respectively. Its high tourist value is also notorious, reinforced by the presence of the "Centro de Visitantes del Árbol Fósil de Hacinas" (www.arbolfosilhacinas.es).

GIP 4: Sad Hill cemetery. Located between the towns of Contreras and Santo Domingo de Silos is the fictional Sad Hill Cemetery (Fig. 4d, f), created in 1966 for the movie "The Good, the Bad and the Ugly". It is a huge cultural experience for anyone who has seen this classic movie since everything in the area is reminiscent of the final famous duel scene. As an additional scientific aspect, observing the paving slabs of the central plaza in detail, it can be seen that they are made up of limestones called oncolytic due to the presence of concentric structures visible to the naked eye, which were built by unicellular organisms named cyanobacteria. The surrounding landscape is also of high value. The weighted assessment of the GIP is 655, of which 195, 235 and 225 correspond to the scientific, educational and tourist value, respectively. The tourist-cultural value of this geological interest point is one of the highest on the itinerary, together with stop 6 (Table 1).

GIP 5: Marine Cretaceous fossils. Located in one of the mountains that surround the Sad Hill Cemetery, to the southwest, on the old road from Contreras to Santo Domingo de Silos (which is a village of great cultural and tourist interest, with a famous Benedictine monastery whose monks actually pray through the Gregorian chant). It is a small abandoned quarry (Fig. 4g), with calcareous marine sediments from the Cretaceous, containing fossils of organisms that lived in the area, especially molluscs. The tourist can easily understand that the region where Dinosaurs lived (GIP 1), with the 


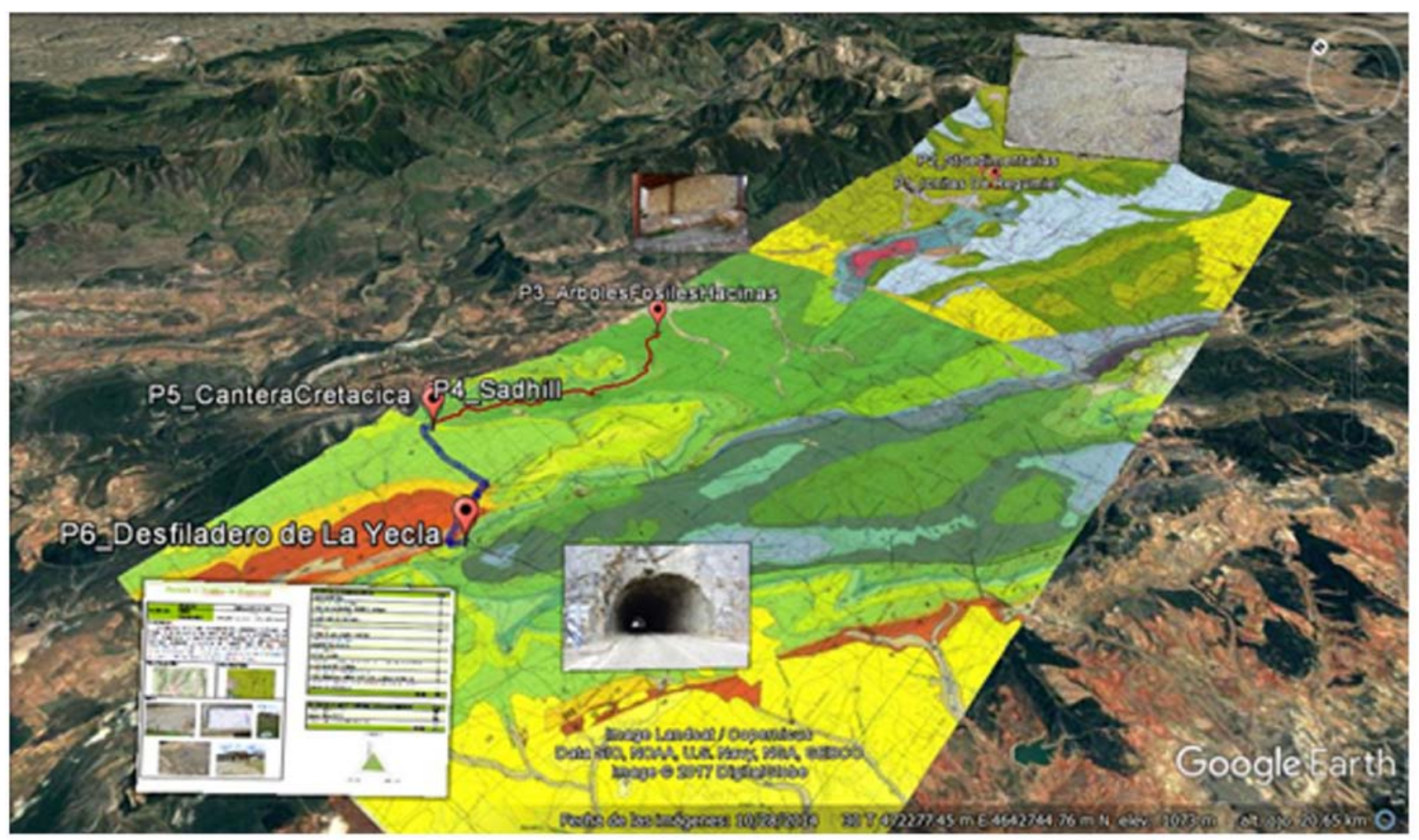

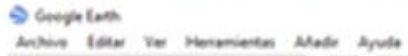

$$
\begin{aligned}
& \text { v Bucar }
\end{aligned}
$$

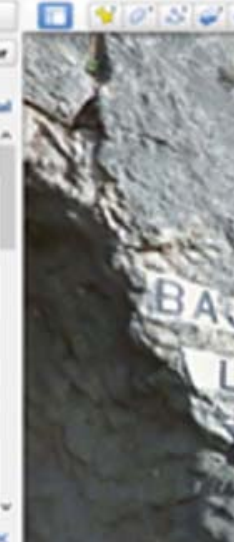

(x)

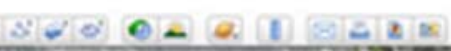

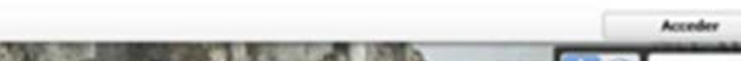

Fig. 5 An aspect of the 3D virtual flight on the Google Earth, with descriptive and graphic information of the itinerary (up), and visualization of the GIP 6 in the "Street View" mode (down)

presence of abundant trees (GIP 3), was later invaded by the sea, as recorded by the marine fossils found at this point. The total weighted assessment is $440(110,185$ and 145 corresponding to the scientific, educational and tourist value, respectively).
GIP 6: La Yecla Gorge. Located in a Protected Natural Area, known as "Yecla Natural Park", this short but deep and narrow river path runs through the steep escarpments of the limestone rocks of Cervera, which serve as home to a large number of griffon vultures. It is formed by a series of bridges 

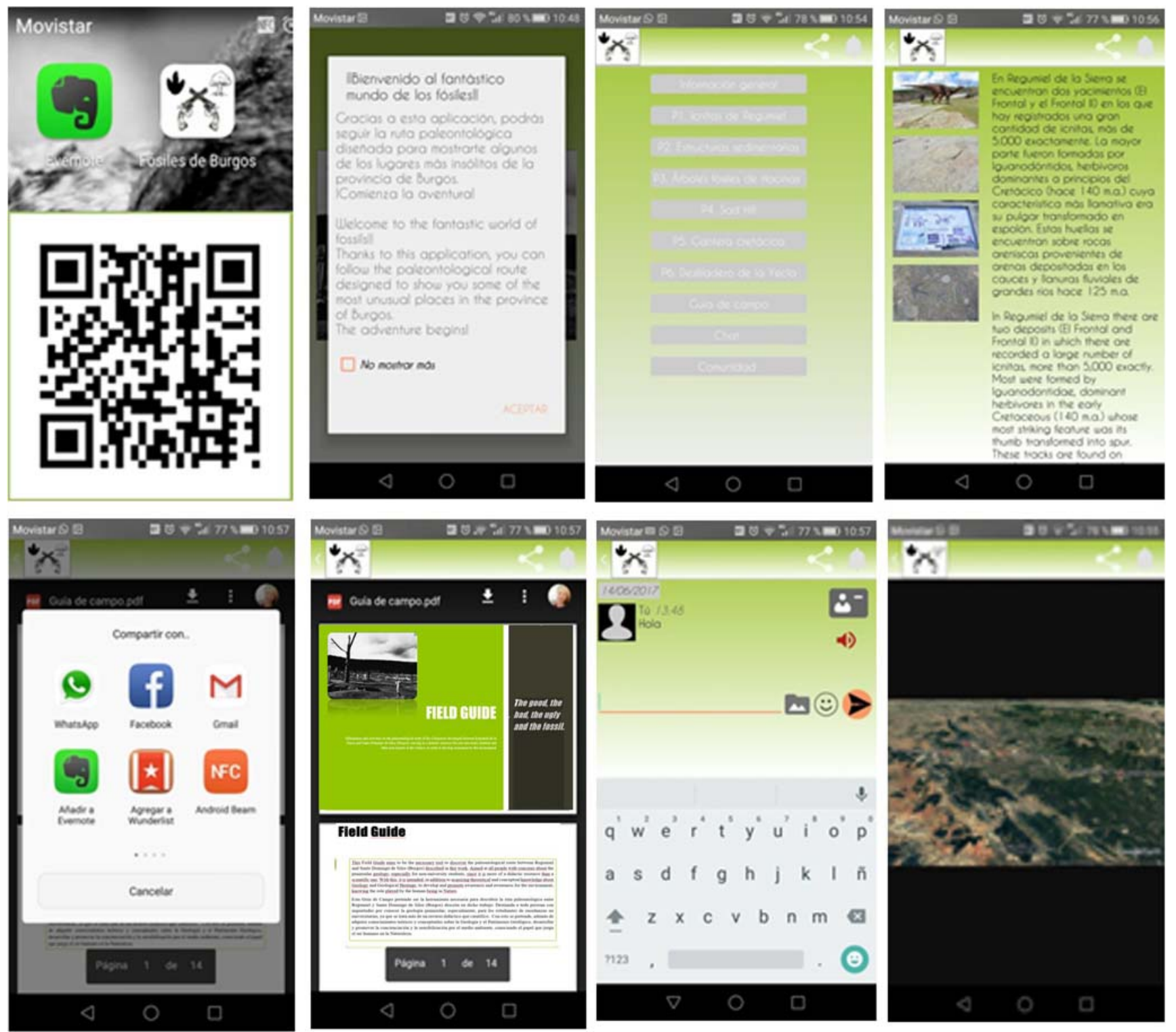

netrumits
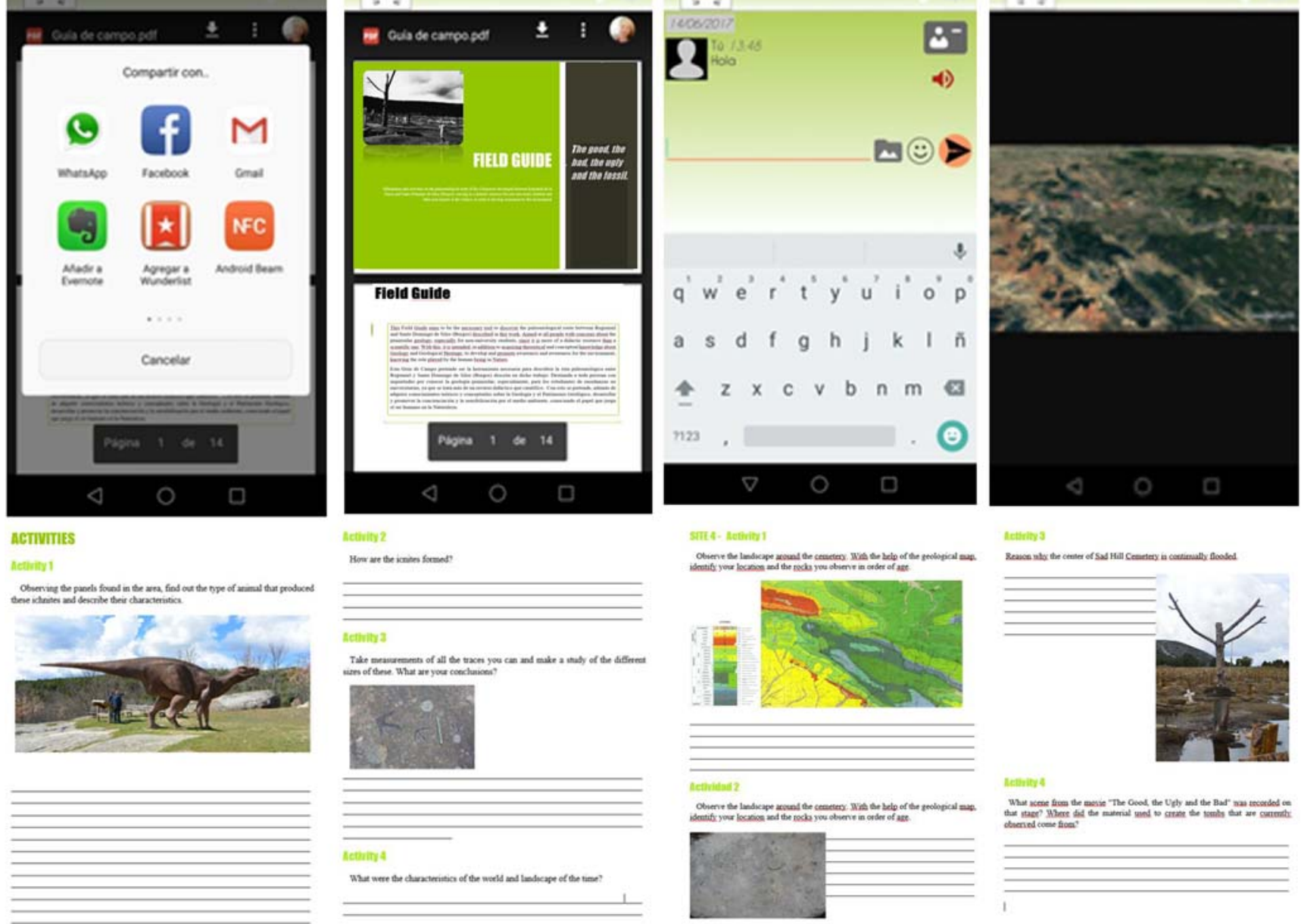

ctitioy

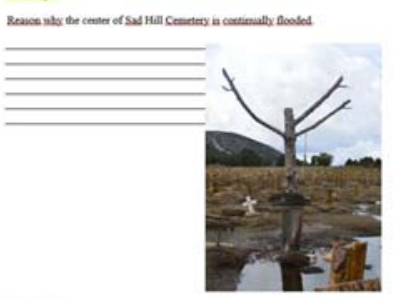

Letirity 4
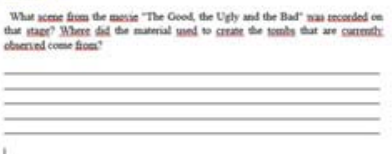

Fig. 6 Screenshots of the geoapp and the QR code, and screen captures of activities of the Field Guide

and footbridges that allow crossing the gorge on the waterfalls and pools of the Helechal river for about $600 \mathrm{~m}$, being able to observe the spectacular surrounding nature, the waterfalls that the stream makes, the drawings and traces of the abrupt walls and numerous morphologies reflecting carbonate dissolution processes (Fig. 4h, i). The total weighted assessment is of 725 , 
the highest of the entire route, of which 195, 305 and 225 correspond to its scientific, educational and touristic value, respectively. This GIP is the one that presents the highest educational and tourist/cultural values of the route (Table 1).

Table 1 shows the valuation of each parameter in the six selected GIPs and the unweighting total sum, as well as the weighting coefficients for the assessment of the scientific, educational and tourist interest.

Table 2 presents the weighted values for the scientific, didactic and cultural interest of each selected GIP.

The GIP 6 (La Yecla gorge) shows the highest unweighted score (44 points), followed by the GIP 4 (Sad Hill) with 41 points, and the GIP 3 (Fossil Trees) with 39. Conversely, the GIP 5 (Cretaceous marine fossils quarry) presents the lowest unweighted score (26 points). The GIPs 1, 3, 4 and 6 have the maximum value of 4 points for the parameter "Learning objectives/educational use" since currently being used in educational activities of Grade and Master's degrees of the Salamanca University. The GIPs 2, 4 and 6 present the maximum valuation for the parameter "State of conservation" as they are intact. In the case of sites 1, 3 and 5, the score is lower because of the slight alteration, without seriously affecting the value or interest of the GIP.

All the GIPS reached high total values. Educational interest is always higher. Concerning the tourist interest, the GIPs 1,3 , 4 and 6 present values above 200 points. It should be highlighted the GIP 6 (La Yecla gorge) with 255 points, well signposted and accessible, located in a small and very narrow gorge (where both sides can be touched with one's hands), as well as the GIP 1 (Dinosaurs tracks of Regumiel) and the GIP 4 (Sad Hill) with 225 points, respectively.

Once all the information has been incorporated using the Google Earth application, following the described methodology, a virtual flight can be generated enabling the observation of the study area prior to the visit. This route can be seen in 3D, using the Google Maps application "Street View" (Fig.5).

The geoapp allows improving the performance during the realisation of the pre-designed paleontological route (Fig. 6). The geoapp starts with a welcome message integrated into a photo of the most touristic place, Sad Hill. Then, the main menu appears with different sections of information for each site, and a chat to the exchange of opinions with other registered users that have made the route, are in it or are going to make it. The access to a community for searching the assistants and the field guide is also available through an enabled link to Drive. By just entering the personal email, the interested user will have full access to the document containing the activities and the information sheet of each stop (supplementary material).

The geoapp for the Android operating system can be downloaded through a link (http://www.androidcreator.com/ app271527) or from a QR code that appears in the panel of each GIP of the route.

\section{Conclusions}

This work provides a methodology for the development of georoutes in favour of the tourism around natural filming locations, as in the case of the well-known Sergio Leone's movie "The Good, the Bad and the Ugly" (1966) in SE of the Burgos province (Spain). The geological and paleontological heritage was valued, and virtual resources have been created using AR, which enhances the touristic-cultural and educational value of the area.

The route designed between the areas of Regumiel de la Sierra and Santo Domingo de Silos presents six GIPs of high scientific, educational and tourist value. The tracks of Dinosaurs (GIP 1) and the iconic cemetery of the "Sad Hill" movie (GIP 4) show high touristic rating (225 points each), but La Yecla gorge (GIP 6 located in a Natural Park) got the highest score, reaching 255 points. Using the Google Earth, a geo-referenced route linked to graphical elements with simple explanations, a geoapp and virtual 3D flights have been created, providing additional geological information of the surrounding environment, easily useable by the tourist of nature, aiming to increase the sustainable development of the region through geotourism.

Acknowledgements This research was funded by projects Junta Castilla y León SA044G18, University of Salamanca USAL2017/46AC01, and Spanish Ministry of Economy and Competitiveness CGL2015-69919-R.

\section{References}

Bailey JE, Chen A (2011) The role of virtual globes in geoscience. Comput Geosci 37:1-2

Balmford A, Beresford J, Green J, Naidoo R, Walpole M, Manica A (2009) A global perspective on trends in nature-based tourism. PLOS Biology 7(6):1000144

Bengoechea A, Izquierdo LA, Martínez JM, Molinero JL, Montero D, Torcida F, Urien V (1993) Icnitas de dinosaurios en el soreste de la provicia de Burgos. Bol Geol Min 104(3):19-34

Cayla N, Hobléa F, Reynard E (2014) New digital technologies applied to the management of geoheritage. Geoheritage 6:89-90

Dowling RK (2013) Global Geotourism-an emerging form of sustainable tourism. Czech J Tour 2(2):59-79

García Cortés A, Carcavilla L (2018) Documento metodológico para la elaboración del Inventario Español de Lugares de Interés Geológico (IELIG). $64 \mathrm{p} \mathrm{https://www.igme.es/patrimonio/descargas/}$ METODOLOGIA\%20IELIG\%20V16\%20actualizaci\%C3\%B3n\% 202018.pdf (accesed on 5 March 2019)

Huerta P, Torcida F, Utiel JC, Montero D (2016) El bueno, el feo y el malo. La geología tras las escenas. Geolodía 2016-Burgos. Field Trip Guide: $1-16$

Lugeri FR, Farabollini P, Greco R, Amadio V (2015) The geological characterization of landscape in major TV series: a suggested approach to involve the public in the geological heritage promotion. Sustainability 7(4):4100-4119 
Martínez-Graña A, Goy J, Cimarra C (2013) Virtual tour of geological heritage: valourising geodiversity using Google Earth and QR code. Comput Geosci 61:83-93

Martínez-Graña AM, González-Delgado JA, Pallarés S, Goy JL, Civis J (2014) 3D virtual itinerary for education using google earth as a tool for the recovery of the geological heritage of natural areas: application in the "Las Batuecas Valley" Nature Park (Salamanca, Spain). Sustainability 6:8567-8591

Martínez-Graña AM, Serrano L, González-Delgado JA, Dabrio CJ, Legoinha P (2017a) Digital geotourism: tools and resources for sustainability and tourism management. Georoute "Route of the fossil footprints" (Monsagro, Salamanca, Spain). Int J Digital Earth 10(2): $121-138$

Martínez-Graña AM, Legoinha P, González-Delgado JA, Dabrio CJ, Pais J, Goy JL, Zazo C, Civis J, Armenteros I, Alonso-Gavilán G, Dias R, Cunha T (2017b) Augmented reality in a hiking tour on the Miocene geoheritage of central Algarve cliffs (Portugal). Geoheritage 9(1):121-131

Martínez-Graña AM, Bajo I, González-Delgado JA, Cárdenas J, Abad M, Legoinha P (2018) Virtual 3D tour applied to the paleontological heritage of the Neogene of Sevilla (Guadalquivir Basin, Spain). Geoheritage 10(3):473-482

Moratalla JJ, Sanz JL, Jiménez S (1994) Dinosaur tracks from the Lower Cretaceous of Regumiel de la Sierra (province of Burgos, Spain): inferences on a new quadrupedal ornithopod trackway. Ichnos 3(2): 89-97

Newsome D, Dowling RK (eds) (2010) Geotourism: the tourism of geology and landscape. Goodfellow Publishers, Oxford

Newsome D, Dowling R, Leung Y, F. (2012) The nature and management of geotourism: a case study of two established iconic geotourism destinations. Tour Manag Perspect 2-3:19-27

Pergams ORW, Zaradic PA (2008) Evidence for a fundamental and pervasive shift away from nature-based recreation. Proc Natl Acad Sci U S A 105(7):2295-2300

Ruban DA (2015) Geotourism - a geographical review of the literature. Tour Manag Perspect 15:1-15

Sriarkarin S, Lee CH (2018) Integrating multiple attributes for sustainable development in a national park. Tour Manag Perspect 28:113-125

Weng Y, Sun F, Grigsby J (2012) Geotools: an android phone application in geology. Comput Geosci 44:24-30 